\section{評価客体としての介護 一史的視点から-}

東北文化学園顧問

\section{今田拓}

介護保険法案は 1996 年国会に提出され，継続 審議中であるが，今後紆余曲折があるにしても， 2 年後には施行の可能性が大きく, 利用手続きの あり方が関心事になっている。

介護という言葉がいつから使われたかを探りな がら，その理由について触れてみたい。

法律的に介護の定義らしい定めを行ったのは, 昭和 62 年制定の社会福祉士および介護福祉士法 と，それに続く福祉関連各法改正であるが，いず れも厳密な定義を避け, 省令で事業を定め, その ような事業の内容が介護である，という構成にな っている。これから決めようとする法定用語に対 して，すでにそ机に近い法定用語がある場合に， このような形がとられることはよくあることで， 「それに近い用語」のターゲットは「看護」であ った．医療との摩擦を避けるためと思われるが， 「介護」は今後も厳密な定義が行われないと思わ れる。

社会福祉関連法文に初めて介護が使われたのは 昭和 38 年の老人福祉法で, 老人ホームへの収容 等の規定に“65歳以上の者であって，身体上又 は精神上著しい欠陥があるために常時の介護を必 要とし...”とあり，これが社会福祉制度に介護と いう言葉が使われた始まりとされるが，すでに昭 和 25 年身体障害者福祉サービス対象者の範囲に 関する通知に“常に就床を要し複雑な介護を要す るもので，回復の見込みのないもの…等”という 文言がある。

介護の範囲については, 昭和 37 年から老人に 対する地域福祉国庫補助事業となった家庭奉仕員 派遣事業の推移に見ることができる。昭和 44 年 寝たきり老人家庭奉仕員制度が発足し，「介護人 の行う介護…」という文言が入り，現在の老人居
宅介護事業に移行している.

25 年昔の国語辞典には載っていない「介護」 は.はじめ，1つの概念として，やがて項目とし て構造化された。社会福祉事業は医療等の保険事 業とは異なり，地方公共団体の委託事業であり， 事業範囲の枠組みは事実上制度的業務独占となる 可能性がある。この演出者は明らかに厚生省社会 局官僚であるが，「介護」はもっと以前から特殊 な場面で使われていた。

たまたま社会保障制度における障害保障に関し て制度間の差異を調べていたところ, 現行の恩給 法の公務傷病による障害の程度別表に，もっとも 重度の特別項症の 1 つとして, “心身障害ノ為自 已身辺ノ日常生活活動ガ全ク不能ニシテ常時複雑 ナル介護ヨ要スルモノ”という文言を見つけた。 恩給法は大正 12 年の制度であるが, 平成 8 年ま でに 75 回の法改正が行われている。 そこで制定 時の恩給法を調べたところ, 上述の現行の別表と ほとんどかわらない法文を見つけた，すなわち恩 給法施行令 24 条の特別項症の一に“常二就床 要シ且複雑ナル介護 7 要スルモノ”とあり, 介護 のルーツは一挙に大正時代にさかのぼる.さらに 歴史を辿ると, そこに日本陸軍の存在が浮かび上 がり，これが軍の用語であったことも明確になっ た。

明治 6 年の徵兵令により国民皆兵となり，これ に伴って明治 8 年「陸軍武官傷痍扶助及ビ死亡ノ 者祭染並二其家族扶助概則」さらに「海軍引隠 令」が制定され，この両制度は明治 23 年の軍人 恩給法へ統合され，大正 12 年の恩給法で文官の 恩給制度と一緒になる。戦争や公務上の傷病につ いて恩給の額を傷病に応じて増加する形をとり, 傷病程度区分が示されている。

制度を引っ張ったのは陸軍であり, 西南の役の 傷病者対策が大きく影響している。傷病の程度の 区分は，時代とともに詳細になり，最重度の表現 に本命の「介護」が出てくる，すなわち，明治 25 年陸軍軍人傷痍疾病恩給等差例改正で, “不具 若クハ廃疾トナリ常ニ介護ヨ要スルモノ八第 1 項 若ク八第 2 項トシ...” という表現があり, 初めて 介護という文言が用いられている。興味があるの 


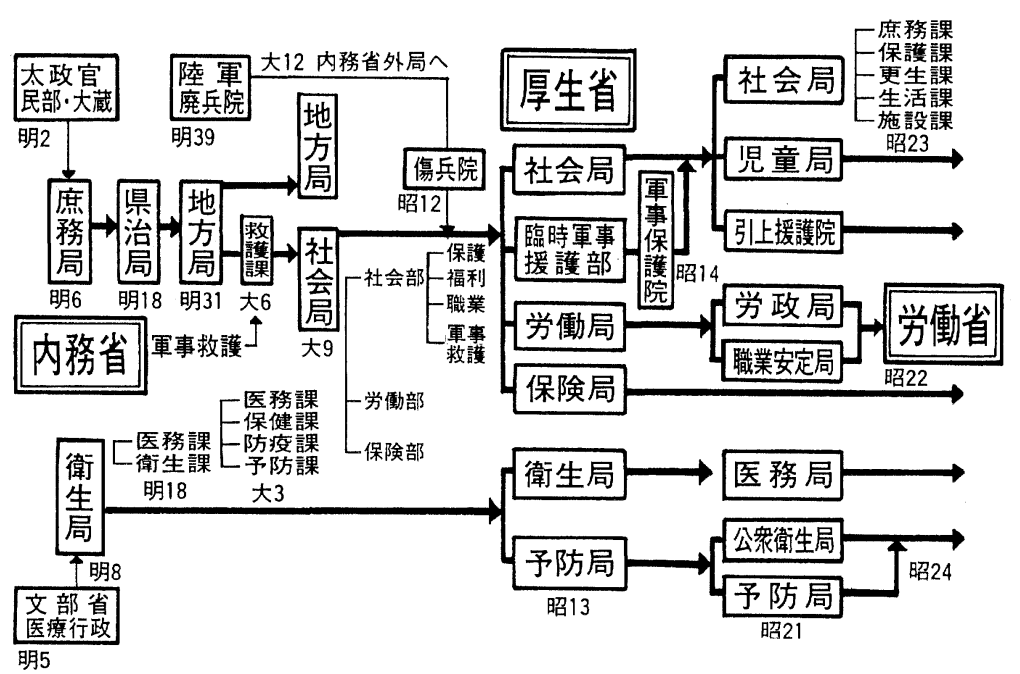

図 1 明治から大戦直後に至る保健・医療・福祉行政組織の変遷

はそれ以前の明治 18 年制定の「官吏恩給令」や 明治 23 年の軍人恩給法の陸軍軍人傷痍疾病恩給 等差例では “不具若ク八廃疾ニシテ起臥飲食意ノ 如クナラス常ニ看護ヨ必要トスルモノ...”となっ ていることである。わずか 2 年の間になぜ看護が 介護になったかは，公的文書からは解答が得られ ない。森林太郎（陸軍軍医団長）編集の「陸軍衛 生制度史」にも改正について詳しく触れている が，その理由は述べられていない。

この間の制度づくりには陸軍，海軍，そして一 般の官吏という三方面からのかかわりがあり，新 しい用語を使うことも主導権を握る戦略の 1 つ で，もっとも経験を重ねた陸軍が主導権を握っ た。また軍医団が軍医学高揚の手段として造った 用語という見方もある。

介護という言葉を造った陸軍が，なぜ福祉と結 びついたかについては，明治から大戦後までの保 健，医療，福祉（実は救貧対策）行政組織の変遷 を知らなければならない（図 1)。救貧対策は明 治 18 年内務省が発足するまでは，太政官直轄で あった，内務省では県治局がこれを担当，明治 31 年地方局となるが，ここで軍事救護業務を内 務省が担当することになり，大正 6 年には救護課 として一課をなすにいたる。 大正 9 年地方局は時 代の要請から, 社会部, 労働部, 保険部からなる 社会局を分身し，社会保障制度の芽吹きとなる。
社会部は保護, 福利, 職業, 軍事救護の 4 課から なり，昭和 13 年発足の厚生省の組織として社会 局，労働局，保険局，臨時軍事援護部が設置され る。その経過の中で，軍事救護の一環として，明 治 39 年設置された廃兵院も大正 12 年陸軍から内 務省に移管される。昭和 14 年臨時軍事援護部は 軍事保護院となり，終戦を迎える。軍事組織は解 体され，新たな社会保障体制が生まれるが，社会 局の本流はそのまま社会福祉行政に移行する。こ の流れは至る所で軍事行政からの流れを吸収しな がら，独自の技術体系を形成してきた．軍事医学 には優れた研究もあったが，切断者の断端訓練で 指摘されるような科学的でない指導も行われた。

社会局行政が目指した具体的な例として，疾病 と障害の峻別である。これは“老衰は病気ではな い”とする考え方と相通じるもので，障害の評価 には独自の別表が用意された。そのルーツに軍の 障害評価があることは疑うべくもなく，独特な更 生指導の手法が中心となった，更生の理念はやが て輸入されたリハビリテーションと同義語とさ れ，社会局がその受け皿となった。残念ながらま だ救貧対策の色彩が強く，“どれだけお金がない か”を計る手段の方ばかりが進み，障害の変遷に 速やかに対応できなかった。例えば身体障害者福 祉施設指導指針の中に昭和 29 年のものが現在で も生きており，そこに示されている運動療法の内 
容には「葡匐」などという軍の演習もどきの言葉 が使われている。

介護保険制度の大きな問題として, 介護度の認 定とケアプランの作成が議論されている. 介護度 と自立度は相反する指標であるが，リハビリテー ション医学関係者は制度を熟知し, さらに制度の 歴史を含む背景を確認しながら, 対象者, 家族, そして社会が納得できる制度を育成することにつ いて，大きな役割を持っている．介護のルーツを 訪ねてちょうど 1 世紀遡った話になったが，介護 を理解するための一助としてお役にたてば幸いで ある。 